\title{
Mannanoligosaccharides or flavomycin in turkeys diets: effect on mucosa-associated microflora and growth performance
}

\author{
E. Wasilewska ${ }^{1,3}$, J. Ratowska $^{1}$, M. Bielecka ${ }^{1}$, Z. Zduńczyk ${ }^{1}$ \\ and J. Jankowski ${ }^{2}$ \\ ${ }^{1}$ Institute of Animal Reproduction and Food Research, Polish Academy of Sciences, \\ Division of Food Science \\ 10-747 Olsztyn, Poland \\ ${ }^{2}$ University of Warmia and Mazury, Department of Poultry Science, \\ Faculty of Animal Bioengineering \\ 10-718 Olsztyn, Poland
}

(Received 13 January 2010; revised version 15 November 2010; accepted 26 November 2010)

\begin{abstract}
Maintaining gut health and well balanced intestinal microflora is important for the profitable production of high quality poultry. We investigated the impact of mannanoligosaccharides (MOS) in comparison with flavomycin on turkeys performance and intestinal colonization by harmful and beneficial microflora. Two hundred forty turkeys (four replicates of 12 birds per treatment) were fed on diet supplemented with flavomycin $(8 \mathrm{mg} / \mathrm{kg}$ feed) or with low $(1 \mathrm{~g} / \mathrm{kg}$ feed during the entire study), medium (4 and $2 \mathrm{~g} / \mathrm{kg}$ feed in the first and second 8-week periods, respectively) and high (10 and $4 \mathrm{~g} / \mathrm{kg}$ feed in the first and second 8-week periods, respectively) level of MOS. Basal diet without supplements was applied as control. After 16 weeks of feeding, the animals were sacrificed and microbial populations (Bifidobacterium, Lactobacillus, streptococci, Escherichia coli and other enterobacteria) attached to the colonic epithelium were assessed. Moreover, colonic epithelia were washed to remove the bound microorganisms and examined for their susceptibility for colonization by exogenous probiotic and pathogenic strains in vitro. In all experimental groups the reduction of the bacteria attached to the epithelium was found, except for increase of streptococci in flavomycinreceiving group and bifidobacteria in flavomycin and MOS-receiving groups. Higher doses of MOS had stimulating effect on body weight gain. In vitro studies revealed a great potential of MOS to reduce attachment of enterobacteria and in higher doses to enhance adhesion of Bifidobacterium and selected Lactobacillus strains $(\mathrm{P} \leq 0.05)$.
\end{abstract}

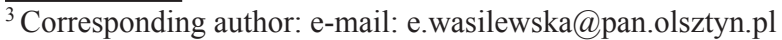


KEY WORDS: turkey, mannanoligosaccharides, microflora, colonization, adhesion, large intestine

\section{INTRODUCTION}

Oligosaccharides, particularly mannanoligosaccharides (MOS), appeared to be very hopeful growth promoters for livestock. Commercially available mannanoligosaccharides are complex carbohydrates extracted from cell wall of yeast Saccharomyces cerevisiae. Added to feed, as entirely safe compounds, MOS appeared to be promising in suppressing enteric pathogens, modulating immune response, and improving integrity of the intestinal mucosa (Iji et al., 2001; Swanson et al., 2002; Elmusharaf et al., 2006). According to current knowledge, MOS prevent bacterial infection via mechanisms that are different from antibiotics, and therefore, circumvent the pathogens ability to develop resistance. Mannanoligosaccharides bind to type-1 fimbriae, i.e. mannose-sensitive lectins on the membranes of pathogenic microorganisms such as Escherichia coli or Salmonella. Blocking of adhesins on pathogenic cells prevents their binding and spreading on the intestinal wall, and initiating of an enteric infection. The neutralized pathogens are finally excreted from the digestive tract in faeces (Doeschate and Kenyon, 1999).

Although MOS is recommended as a natural growth promoter, published reports on the use of MOS in poultry feeding are still inconsistent. Many authors described not evident effect of MOS on body weight and proper microflora balance (Hooge, 2004; Yang et al., 2007). This is partly due to variability of the applied doses of MOS, and because most of the studies on the microflora in chickens have looked only at the protective effect of orally administered caecal cultures or MOS against enteropathogen challenge, mostly Salmonella. More extensive microbiological studies were not performed (Yu et al., 1999; Hooge, 2004).

According to current knowledge, the supposed suppressive effect of MOS upon pathogens seems to be confirmed. However, at the same time a tendency to suppress beneficial microflora was observed (Hooge, 2004; Yang et al., 2008). Our previous studies showed that dietary MOS added in amount $1-10 \mathrm{~g} / \mathrm{kg}$ diet significantly decreased $E$. coli counts in caecal contents, especially when applied in higher concentrations, but also tended to decrease the populations of Bifidobacterium and Lactobacillus (Zdunczyk et al., 2005).

The commensal colonic microflora is specific to each individual and should remain stable over time, largely due to a protective effect of the microflora itself, referred to as the barrier effect (Rambaud et al., 2006). Microbial communities associated with epithelial surfaces are of great importance, as they serve to block an access to the intestine for pathogens and to stabilize the composition of the gut microflora. 
There is a lack of information on how the presence of MOS, comparably to antibiotics, influences colonization of the intestinal epithelium by both endogenous and exogenous bacteria. Competition for receptors on the intestinal wall is one of the mechanisms that are instrumental in the inhibitory effect of beneficial microorganisms, including probiotics, against pathogen invasion. Thus, based on this fact it can be hypothesized that an increase in the number of beneficial microorganisms as well as a decrease in the number of pathogenic bacteria colonizing the intestinal epithelium results in the increased protective effect, and vice versa. The goal of this study was to asses whether diets supplemented with flavomycin or MOS alter bacterial colonization pattern, and thus protective barrier effect of the intestine. To this purpose we analysed changes in beneficial and opportunistic endogenous microflora settled on the colonic epithelia of turkeys fed the diets containing flavomycin or different amount of MOS. Moreover, susceptibility of these epithelia to colonization by harmful and beneficial exogenous microflora was investigated in vitro. Standard diet without supplements was applied as control.

\section{MATERIAL AND METHODS}

\section{Birds and diets}

The experiment was conducted at the State Turkey Evaluation Station of the Warmia and Masuria University (UWM) in Olsztyn on 240 3-day-old BUT-9 turkey chickens randomly assigned to five dietary treatments, each with four replicates (12 toms in each). The turkeys were kept under standard environmental and lighting conditions. The birds were given free access to mash diets consisting of the basal diet $(980 \mathrm{~g} / \mathrm{kg})$, mineral and vitamin premix (with or without antibiotic, $10 \mathrm{~g} / \mathrm{kg}$ feed) and up to $10 \mathrm{~g}$ of supplemental mannanoligosaccharides (MOS) given instead of maize (Table 1). The basal diet was formulated to meet the nutrient requirements for turkey and it was changed every four weeks. For 1-4, 5-8, 9-12 and 13-16 week of feeding the basal diet included (g per kg): wheat 246, 281, 210 and 405; maize 200, 200, 318 and 250; soyabean meal 420,410, 340 and 260; fish meal 30, 30, 30 and 0; meat meal 50, 0,0 and 0 ; soyabean oil 19, 35, 54 and 45, respectively. In the control diet, a premix without an antibiotic and MOS was applied. The experimental diets contained flavomycin $(8 \mathrm{mg} / \mathrm{kg}$ feed) or low $(1 \mathrm{~g} / \mathrm{kg}$ feed during the entire study; MOS-L group), medium (4 and $2 \mathrm{~g} / \mathrm{kg}$ feed in the first and second 8 -week periods, respectively; MOS-M) or high (10 and $4 \mathrm{~g} / \mathrm{kg}$ feed in the first and second 8-week periods, respectively; MOS-H) level of MOS preparation 
Table 1. Composition of experimental diets ${ }^{1}, \mathrm{~g} / \mathrm{kg}$

\begin{tabular}{|c|c|c|c|c|c|}
\hline \multirow{2}{*}{ Item } & \multicolumn{5}{|c|}{ Diet } \\
\hline & control & flavomycin $^{2}$ & $\mathrm{MOS}^{3}-\mathrm{L}$ & MOS-M & MOS-H \\
\hline $\begin{array}{c}\text { 1-8 week of feeding } \\
\text { basal diet }\end{array}$ & \multicolumn{4}{|c|}{ 1-8 week of feeding } & 980 \\
\hline \multicolumn{6}{|l|}{ Premix } \\
\hline without antibiotic & 10 & - & 10 & 10 & 10 \\
\hline \multicolumn{6}{|l|}{ supplemental MOS } \\
\hline MOS & - & - & 1 & 4 & 10 \\
\hline maize & 10 & 10 & 9 & 6 & - \\
\hline \multicolumn{6}{|l|}{ 9-16 week of feeding } \\
\hline basal diet & 980 & 980 & 980 & 980 & 980 \\
\hline Premix & & & & & \\
\hline without antibiotic & 10 & - & 10 & 10 & 10 \\
\hline $\begin{array}{l}\text { with antibiotic }{ }^{2} \\
\text { supplemental MOS }\end{array}$ & - & 10 & - & - & - \\
\hline MOS & _ & _ & 1 & 2 & 4 \\
\hline maize & 10 & 10 & 9 & 8 & 6 \\
\hline
\end{tabular}

${ }^{1}$ two diets for the 1-4 and 5-8 weeks of feeding containing (calculated analysis on basis of air dry feed): MJ/kg: ME 11.4 and 11.7; g/kg: crude protein 288.7 and 259.3, crude fibre 34.0 and 36.7, crude fat - 44.0 and 55.1, L-lysine 18.0 and 16.5, DL-methionine + cysteine 11.6 and 10.6, Cal 12.8 and 11.4, phosphorus available 7.2 and 6.9 , Nat 1.5 and $1.5 ; \mathrm{mg} / \mathrm{kg}$ : Sel 0.3 and 0.3 , vit. E 40 and 35; IU/kg: vit. A 15000 and 13000, respectively

two diets for the 9-12 and 13-16 weeks of feeding containing (calculated analysis on basis of air dry feed): $\mathrm{MJ} / \mathrm{kg}$ : ME 12.5 and 12.6; g/kg: crude protein 229.2 and 187.8 , crude fibre 30.8 and 30.0, crude fat 76.4 and 65.6, L-lysine 14.0 and 12.0, DL-methionine + cysteine 9.8 and 7.3, Cal 11.9 and 10.1 , phosphorus available 6.7 and 5.0, Nat 1.6 and $1.4 ; \mathrm{mg} / \mathrm{kg}$ : Sel 0.3 and 0.3 , vit. E 30 and 30; IU/kg: vit. A 12000 and 12000, respectively

${ }^{2}$ flavomycin $8 \mathrm{mg} / \mathrm{kg}$ diet; ${ }^{3}$ mannanoligosaccharides

(Biomos, Alltech, Inc. Nicholasville, KY). The experiment lasted 16 weeks. At the conclusion of the experiment the birds were weighed and 8 randomly selected turkeys from each group were killed according to the recommendations for euthanasia of experimental animals (Close et al., 1997). As soon as possible after euthanasia, the colons were extracted and after gently expelling the intestine's content, immediately frozen in liquid nitrogen and stored at $-80^{\circ} \mathrm{C}$ until testing.

The animal protocol for these studies was approved by the Animal Care and Use Committee of the UWM.

\section{Analysis of endogenous microflora colonizing the colon epithelium}

Populations of five groups of microflora (Bifidobacterium, Lactobacillus, streptococci, Escherichia coli and other enterobacteria) attached to the colonic epithelium were determined. Unfrozen $\left(\right.$ at $37^{\circ} \mathrm{C}$ ) colons were opened, gently 
washed five times in fresh phosphate buffered saline (PBS, $\mathrm{pH}$ 7.2) to remove intestinal content and unbound bacteria, cut into pieces with an epithelium area about $1.0 \mathrm{~cm}^{2}$ and immediately analysed. For analysis of the attached endogenous microflora, $1.0 \mathrm{~cm}^{2}$ pieces of the previously washed colons were weighed, macerated in PBS at $4^{\circ} \mathrm{C}$ for $30 \mathrm{~min}$ in order to loosen surface mucus and attached bacteria, cut into small pieces, and homogenized at 12,500 rotations per min for $30 \mathrm{~s}$ (Ultra-Turax T25 basic, IKA ${ }^{\circledR}$-WERKE, Germany) to detach bound microorganisms. The homogenates were serially diluted, in half-strength anaerobic peptone water (Wasilewska et al., 2008), and plated for colony forming units (CFU) determination. The live cells of bifidobacteria and lactobacilli were counted according to the procedure described by Biedrzycka et al. (2003), streptococci were counted on M17 agar on the basis of characteristic cellular morphology checked microscopically (MICROPHOT FXA, Nikon, phase contrast technique), and Escherichia coli and other enterobacteria were counted according to the procedure described previously (Zdunczyk et al., 2005) on McConkey Purple agar. E. coli was differentiated from other enterobacteria on the basis of E. coli yellow colour of colonies, which appeared during 24-h incubation. The results of microbiological tests were expressed as colony-forming units per gram of the intestine.

Studies on mucosal adhesiveness of the epithelium - in vitro adhesion assay

Bacterial strains and culture conditions. Probiotic bacteria belonging to the genera: Bifidobacterium (B. animalis subsp. lactis J38 and BI30), Lactobacillus (L. salivarius AWH, L. rhamnosus 8/4, L. casei LCY), and Streptococcus (S. thermophilus TKM3 and MK10), as well as pathogenic bacteria belonging to genera Escherichia (E. coli O157:H7 and H1) and Salmonella (S. enteritidis 491 and KOS64, and S. typhimurium 35) were applied in the studies. Probiotic strains originated from own collection and were identified to species level using phenotypic and molecular methods (Wasilewska et al., 2003; Markiewicz et al., 2009). The strains of Salmonella and Escherichia were obtained from the Culture Collection of the Veterinary Institute in Pulawy (Poland), the Veterinary Hygiene Department, and the Sanitary and Epidemiology Station in Olsztyn (Poland). MRS, M 17, modified Garche's broth (Wasilewska et al., 2008), and hydrolysed milk enriched by yeast extract and $\mathrm{NaCl}$ ( 3 and $5 \mathrm{~g} / \mathrm{l}, \mathrm{pH}$ 6.6) were applied for Lactobacillus, Streptococcus, Bifidobacterium and Escherichia or Salmonella cells multiplying, respectively. Incubation of the strains was carried out at $37^{\circ} \mathrm{C}$ until stationary phase was achieved, under aerobic conditions, except for the Bifidobacterium strains which were incubated in anaerobic jars (Gas Pak anaerobic system $\mathrm{H}_{2}+\mathrm{CO}_{2}$, Oxoid, $\mathrm{UK}$ ). All strains were stored frozen at $-80^{\circ} \mathrm{C}$. 
Before every experiment, strains from frozen stocks were subcultured twice in appropriate nutrient broth using 3\% inoculum (vol/vol).

Adhesion assay. Active bacterial cultures were harvested by centrifugation (4500 $\mathrm{g} / 10 \mathrm{~min}$ ), washed twice with PBS, and resuspended in PBS to about $5 \times 10^{8}$ cells per $\mathrm{ml}\left(\mathrm{OD}_{600}=1.0\right)$. The unfrozen and washed colon pieces of about $1.0 \mathrm{~cm}^{2}$ were macerated in PBS at $4^{\circ} \mathrm{C}$ for $30 \mathrm{~min}$ in order to loosen surface mucus and attached bacteria, and again washed intensively five times in PBS. Afterwards, the pieces were weighed and introduced into 6-well polystyrene plates each containing $5 \mathrm{ml}$ of the previously prepared bacterial suspensions. The colon pieces were placed in wells in a way to secure direct contact of bacteria with the epithelium surface. The pieces immersed in wells with PBS without bacteria were used as controls. After incubation for $1 \mathrm{~h}$ at $37^{\circ} \mathrm{C}$, the pieces were taken out and washed by five times serial immersing in fresh PBS to remove unattached bacterial cells, cut up, homogenized, and plated for CFU determination as described previously. The amount of bacteria remaining on the washed epithelium used for adhesion assay was determined separately for all bacterial groups tested and was subtracted from in vitro adhesion results. The adhesion was expressed as the number of bacterial cells attached per $\mathrm{g}$ of the intestine.

\section{Statistical analysis}

The results were subjected to statistical analysis using the one way ANOVA test and STATISTICA 6 software (StatSoft, Poland). Significance of differences between groups was determined by the Duncan's multiple range test. Differences were considered significant at $\mathrm{P} \leq 0.05$.

\section{RESULTS}

Animal growth and feed conversion. Feed intake and feed conversion ratio (FCR) were similar in all groups, whereas, the body weight gain differed (Table 2). The turkeys fed the diet containing medium level of MOS (MOS-M group) had the highest body weight gain and it significantly differed from the birds in the control, flavomycin and MOS-L groups. There was no considerable difference between MOS-M and MOS-H groups, however, the birds fed the diet containing high level of MOS significantly differed in body weight gain only from the flavomycin receiving turkeys. Mortality rate was considered normal and was not affected by the treatments $(2.0 \%$, on average). 
Table 2. Effects of dietary flavomycin and mannanoligosaccharides on growth performance of turkeys

\begin{tabular}{lcccccc}
\hline \multirow{2}{*}{ Parameter } & \multicolumn{5}{c}{ Diet $^{1}$} & \multirow{2}{*}{ SEM $^{2}$} \\
\cline { 2 - 6 } & control & flavomycin & MOS-L & MOS-M & MOS-H & \\
\hline Feed intake, kg/turkey & 32.85 & 32.71 & 32.83 & 33.68 & 33.59 & 0.27 \\
Body weight gain, kg & $13.73^{\mathrm{bc}}$ & $13.48^{\mathrm{c}}$ & $13.77^{\mathrm{bc}}$ & $14.34^{\mathrm{a}}$ & $14.10^{\mathrm{ab}}$ & 0.09 \\
$\mathrm{FCR}^{3}, \mathrm{~kg} / \mathrm{kg}$ & 2.39 & 2.42 & 2.38 & 2.35 & 2.38 & 0.01 \\
\hline
\end{tabular}

${ }^{1}$ control - basal without supplements; flavomycin - supplemented with $8 \mathrm{mg}$ flavomycin/ $\mathrm{kg}$, MOS-L - supplemented with mannanoligosaccharides (MOS), $1 \mathrm{~g} / \mathrm{kg}$ during entire study; MOS-M - supplemented with MOS, 4 and $2 \mathrm{~g} / \mathrm{kg}$ in the first and second 8-week periods, respectively; MOS-H - supplemented with MOS, 10 and $4 \mathrm{~g} / \mathrm{kg}$ in the first and second 8-wk periods, respectively; ${ }^{2}$ standard error of the mean; ${ }^{a, b, c}$ values within each row with different superscripts are different at $\mathrm{P} \leq 0.05 ;{ }^{3}$ feed conversion ratio

Analysis of endogenous microflora colonizing the colonic epithelium. The numbers of the cultivable bacteria colonizing the colonic epithelium of turkeys are presented in Table 3. The Bifidobacterium and Lactobacillus counts were determined as genera entirely positive for host's health, whereas enterobacteria, including E. coli, were typical representatives for opportunistic microflora. In the control group of turkeys, lactobacilli and streptococci dominated, and amounted about $3 \times 10^{5} \mathrm{CFU} / \mathrm{g}$ of the intestine each. The Bifidobacterium and E. coli had approximately 10-times lower counts, whereas the group comprising remaining enterobacteria was lower by about 1000-times than those of lactobacilli and streptococci. Supplementation with flavomycin caused numerical increase in streptococci and Bifidobacterium, and decrease in Lactobacillus and all enterobacteria, but except for enterobacteria the changes in population density were not statistically different from the control. In all groups of turkeys fed diets containing the increasing doses of MOS a decreasing tendency in the counts of Lactobacillus and streptococci was stated, the differences were, however, significant only in comparison to the control and flavomycin-receiving groups for Lactobacillus and streptococci, respectively $(\mathrm{P} \leq 0.05)$. Considerable reduction in the streptococci density in the MOS-L group in comparison to the

Table 3. Effects of dietary flavomycin and mannanoligosaccharides on selected bacterial groups colonizing the large intestine of turkeys in vivo, CFU/g of the intestine, $\mathrm{x} 10^{3}$

\begin{tabular}{lcccccc}
\hline \multirow{2}{*}{ Bacterial groups } & \multicolumn{5}{c}{ Diet $^{1}$} & \multirow{2}{*}{ SEM $^{2}$} \\
\cline { 2 - 5 } & control & flavomycin & MOS-L & MOS -M & MOS -H & \\
\hline Lactobacillus & $328.30^{\mathrm{a}}$ & $185.8^{\mathrm{ab}}$ & $35.2^{\mathrm{b}}$ & $27.8^{\mathrm{b}}$ & $49.2^{\mathrm{b}}$ & 34.2 \\
Bifidobacterium & 73.1 & 143.0 & 61.2 & 171.7 & 242.7 & 37.5 \\
Streptococci & $305.8^{3 \mathrm{ab}}$ & $537.2^{\mathrm{a}}$ & $21.6^{\mathrm{c}}$ & $48.2^{\mathrm{bc}}$ & $57.8^{\mathrm{bc}}$ & 52.9 \\
Escherichia coli & $18.8^{\mathrm{a}}$ & $0.9^{\mathrm{b}}$ & $3.8^{\mathrm{b}}$ & $0.4^{\mathrm{b}}$ & $5.6^{\mathrm{b}}$ & 2.0 \\
Other enterobacteria & $0.27^{\mathrm{a}}$ & $0.01^{\mathrm{c}}$ & $0.03^{\mathrm{c}}$ & $0.06^{\mathrm{bc}}$ & $0.21^{\mathrm{ab}}$ & 0.03 \\
\hline
\end{tabular}

${ }^{1}$ as in Table $2 ;{ }^{2}$ standard error of the mean, ${ }^{a, b, c}$ values within each row with different superscripts are different at $\mathrm{P} \leq 0.05$ 
control group was observed as well $(\mathrm{P} \leq 0.05)$. The population of Bifidobacterium enlarged in the MOS-M and MOS-H groups in comparison to both control and flavomycin receiving birds, but differences were not significant statistically. Lowest amount of bifidobacteria, but comparable to the control group, was stated in the MOS-L group. In all MOS-receiving turkeys, the E. coli counts were considerably lower than in the control $(\mathrm{P} \leq 0.05)$. However, the mean number of $E$. coli cells colonizing the epithelia of MOS-receiving turkeys tended to be greater in the MOS-L and MOS-H groups and smaller in the MOS-M group in comparison to the flavomycin-receiving birds. A count of the other enterobacteria depended on the applied dose of MOS, and was the highest (comparable to control group) in the MOS-H group. A considerable decrease in the enterobacteria cells in MOS-L and MOS-M groups and an increase in the MOS-H group were stated in comparison to control and flavomycin-receiving turkeys, respectively $(\mathrm{P} \leq 0.05)$.

Influence of MOS on bacterial adhesion - in vitro studies. The influence of flavomycin and MOS on adhesion and colonization of the intestine by exogenic beneficial or harmful bacteria was examined in vitro. Results are presented in Table 4 and Figure 1. S. thermophilus, L. rhamnosus, L. salivarious, L. casei and $B$. lactis strains were chosen as representing beneficial bacterial species most frequently used in the food industry, whereas Salmonella and E. coli strains are typical representatives of harmful and opportunistic microflora.

Table 4. Effects of dietary flavomycin and mannanoligosaccharides on in vitro adhesion of potentially beneficial and pathogenic bacteria to the large intestine of turkeys, CFU number/g of the intestine ${ }^{1}$, $\mathrm{x} 10^{6}$

\begin{tabular}{|c|c|c|c|c|c|c|}
\hline \multirow{2}{*}{ Bacteria } & \multicolumn{5}{|c|}{ Diet $^{2}$} & \multirow{2}{*}{$\mathrm{SEM}^{3}$} \\
\hline & control & flavomycin & MOS -L & MOS-M & MOS-H & \\
\hline \multicolumn{7}{|l|}{ Beneficial strains } \\
\hline S. thermophilus TKM3 & $26.5^{\mathrm{b}}$ & $29.4^{\mathrm{b}}$ & $30.2^{\mathrm{b}}$ & $84.3^{\mathrm{a}}$ & $30.4^{\mathrm{b}}$ & 8.2 \\
\hline S. thermophilus MK10 & $71.3^{\mathrm{a}}$ & $51.9^{\mathrm{ab}}$ & $22.6^{\mathrm{b}}$ & $24.2^{\mathrm{b}}$ & $26.0^{\mathrm{b}}$ & 6.9 \\
\hline L. rhamnosus 8/4 & $110.0^{\mathrm{b}}$ & $62.2^{\mathrm{b}}$ & $73.2^{\mathrm{b}}$ & $102.8^{\mathrm{b}}$ & $187.8^{\mathrm{a}}$ & 13.1 \\
\hline L. salivarius AWH & $44.5^{\mathrm{b}}$ & $22.0^{\mathrm{b}}$ & $18.4^{\mathrm{b}}$ & $34.7^{\mathrm{b}}$ & $242.8^{\mathrm{a}}$ & 21.1 \\
\hline L. casei LCY & $64.0^{\mathrm{ab}}$ & $33.0^{\mathrm{b}}$ & $60.6^{\mathrm{ab}}$ & $48.0^{\mathrm{ab}}$ & $92.2^{\mathrm{a}}$ & 7.2 \\
\hline B. lactis $\mathrm{J} 38$ & $69.3^{\mathrm{a}}$ & $175.8^{\mathrm{b}}$ & $174.5^{\mathrm{b}}$ & $264.3^{\mathrm{b}}$ & $267.7^{\mathrm{b}}$ & 19.7 \\
\hline B. lactis $\mathrm{BI} 30$ & $92.7^{\mathrm{c}}$ & $195.8^{\mathrm{bc}}$ & $182.2^{\mathrm{bc}}$ & $211.0^{\mathrm{b}}$ & $338.7^{\mathrm{a}}$ & 21.2 \\
\hline \multicolumn{7}{|l|}{ Pathogenic strains } \\
\hline E. coli $\mathrm{O} 157: \mathrm{H} 7$ & $94.2^{\mathrm{b}}$ & $161.7^{\mathrm{a}}$ & $68.5^{\mathrm{bc}}$ & $49.5^{\mathrm{c}}$ & $33.8^{\mathrm{c}}$ & 9.7 \\
\hline E. coli $\mathrm{H} 1$ & $100.5^{\mathrm{ab}}$ & $121.2^{\mathrm{a}}$ & $34.5^{\mathrm{c}}$ & $76.8^{\mathrm{bc}}$ & $74.3^{\mathrm{bc}}$ & 8.1 \\
\hline S. enteritidis 491 & $184.0^{\mathrm{a}}$ & $185.5^{\mathrm{a}}$ & $55.2^{\mathrm{bc}}$ & $104.2^{\mathrm{bc}}$ & $113.2^{\mathrm{b}}$ & 11.9 \\
\hline S. typhimurium 35 & $156.5^{\mathrm{ab}}$ & $200.7^{\mathrm{a}}$ & $60.3^{\mathrm{c}}$ & $124.7^{\mathrm{bc}}$ & $109.8^{\mathrm{bc}}$ & 13.6 \\
\hline S. enteritidis KOS64 & $48.2^{\mathrm{ab}}$ & $26.1^{\mathrm{bc}}$ & $18.7^{\mathrm{c}}$ & $42.0^{\mathrm{abc}}$ & $53.7^{\mathrm{a}}$ & 4.1 \\
\hline
\end{tabular}

${ }^{1}$ the amount of bacteria remaining on the washed epithelium used for adhesion assay (amounted circa about $5 \times 10^{3}$ and $5 \times 10^{4} \mathrm{CFU}$ per $\mathrm{g}$ of intestine for enterobacteria and lactic acid bacteria including bifidobacteria, respectively) was subtracted from the results; ${ }^{2}$ as in Table $2 ;{ }^{3}$ standard error of the mean, ${ }^{a, b, c}$ values within each row with different superscripts are different at $\mathrm{P} \leq 0.05$ 


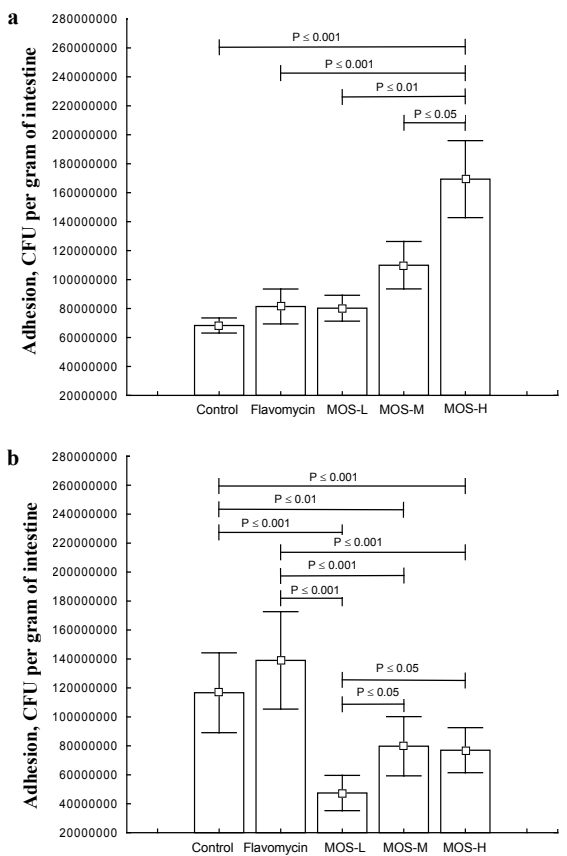

Figure 1. Effects of dietary flavomycin and mannanoligosaccharides on in vitro adhesion of all beneficial (a) and pathogenic (b) bacteria to the large intestine of turkeys, CFU/g of the intestine (mean and SE). Supplements in diets as described in Table 2

In the control group, Salmonella and E. coli strains adhered to the epithelium in the highest numbers (about $10^{8} \mathrm{CFU} / \mathrm{g}$ ) followed by Bifidobacterium, Lactobacillus and Streptococcus strains (Table 4). Addition of flavomycin to the diet did not significantly influence the binding of the bacterial strains except for greater adhesion of Bifidobacterium and E. coli strains $(\mathrm{P} \leq 0.05)$ and a tendency to lower attachment of Lactobacillus strains. Feeding the birds with diets containing different amounts of MOS altered the ability of the colonic epithelium to interact with the bacteria tested. Generally, a decrease in attachment of pathogenic and an increase in attachment of probiotic strains were stated but the extent of the adhesion depended on a strain and an applied dose of MOS. The greatest reduction of pathogen binding was observed in the MOS-L group. In these turkeys, from among five enterobacteria strains tested, adhesion of four was significantly lowered in comparison with the control group, whereas only two in the MOS-M and MOS-H groups $(\mathrm{P} \leq 0.05)$. Inversely, the greatest stimulation of adhesion of beneficial bacteria was found in the MOS-H group. However, similarly as pathogenic bacteria, the tested probiotic strains differed 
in their ability to bind to colonic epithelium of the MOS-receiving turkeys. The attachment of both Bifidobacterium strains tested was significantly increased by the increasing doses of MOS $(\mathrm{P} \leq 0.05)$. The highest attachment of Lactobacillus strains was found in the group receiving the highest amount of MOS, however in comparison with control, the differences were significant only for $L$. rhamnosus $8 / 4$ and L. salivarious AWH strain $(\mathrm{P} \leq 0.05)$. In regard to Streptococcus thermophilus, feeding turkeys with all diets of MOS caused significant decrease of attachment of MK10 strain $(\mathrm{P} \leq 0.05)$, while an increase of adhesion of TKM3 strain in MOSM-group ( $\mathrm{P} \leq 0.05)$.

Figure 1 illustrates a comparison of mean in vitro adhesion of all beneficial and pathogenic bacteria under study. The analysis confirmed that MOS most effectively enhanced adhesion of beneficial bacteria when was applied in the highest dose, whereas, the greater reduction of attachment of pathogenic bacteria was found in the MOS-L-receiving turkeys, in comparison with both control and flavomycinreceiving groups $(\mathrm{P} \leq 0.001)$.

\section{DISCUSSION}

Bacteria bound to the epithelium are crucial for regeneration and maintenance of 'proper' microflora composition settled in lumen content, but disrupted by exogenous factors (Rambaud et al., 2006). There is lack of information how antibiotics in feed influence bacterial populations attached to the intestine. Our studies revealed that flavomycin in a dose $8 \mathrm{mg}$ per $\mathrm{kg}$ feed mixture significantly decreased the amount of enterobacteria cells attached to colonic epithelium. Simultaneously, an increase in the number of attached streptococci and bifidobacteria, and a reduction in beneficial Lactobacillus cells attached to the intestine occurred (Table 3). Lactobacilli possess a great ability to adhere to the intestinal epithelium and to prevent potential infection by competitive exclusion (Tierney et al., 2004; Lin et al., 2007). Similarly, Bifidobacterium strains are commonly considered as key commensals that promote health of the gut. The performed in vivo and in vitro studies revealed that flavomycin increased abilities of the colonic epithelium to bind bifidobacteria. It may be a result of some modifications in the receptor structures provoked by changed microbiological balance caused by extinction of flavomycinsensitive bacteria. It fits into the theory of the mechanism of protective effect of antibiotics in animal breeding. Sims et al. (2004) showed stimulating effect of dietary antibiotics on bifidobacteria population in turkeys gut. However, our studies revealed that the intestines became more susceptible to colonization by 
some exogenous strains. One of the two E. coli strains tested, adhered in vitro significantly stronger to the colonic epithelium of flavomycin-receiving turkeys. Lower adhesion of the beneficial Lactobacillus strains was also observed.

Mannanoligosaccharides are perceived as an alternative for antibiotic growth stimulators. So far, various investigators have reported on lack or diverse influence of MOS on bacterial populations in the gut (Hooge, 2004; Yang et al., 2007, 2008, 2009). Our results revealed significant reduction of the amount of bacteria attached to the epithelium of MOS receiving turkeys, mainly because of significant decrease in enterobacteria, lactobacilli and streptococci numbers. Interestingly, the higher reduction of the epithelium-associated bacteria was observed in the two groups receiving smaller doses of MOS. As it was recently analysed by Yang et al. (2009), the optimal dose of MOS for broiler production appears to be approximately $2 \mathrm{~g} / \mathrm{kg}$ of feed mixture, depending on the production stage of birds. Our studies revealed that a limited amount of MOS ( $1 \mathrm{~g} / \mathrm{kg}$ diet $)$ had no impact on turkeys' performance, whereas, applied in higher dietary concentrations it significantly enhanced body weight gain. Thus, research into optimal supplementation is still inconclusive. It maybe stipulated that co-supplementation of a diet with some probiotic bacteria would enhance the effect of MOS served in smaller doses. Brzóska et al. (2007) described the positive effect of limited amount of MOS in the diet $(1 \mathrm{~g} / \mathrm{kg}$ diet) in combination with lactic acid bacteria on broilers performance. The critical point of bacterial contamination of poultry products occurs at the slaughter house when pathogens from the intestinal contents make contact with chicken carcasses (Heyndrickx et al., 2002). Thus, besides of health and breeding aspects, lowering level of beneficial microflora in the intestine could be inconvenient to keep carcasses in good condition.

The performed in vitro studies demonstrated different susceptibility of the epithelia of MOS receiving turkeys to colonization by exogenic strains. Generally, the colonic epithelia of turkeys fed MOS-containing diets were characterized by smaller ability to bind E. coli and Salmonella strains, and the tested feature seems to be strain- or dose-dependent. Similarly, adhesion of the tested Streptococcus and Lactobacillus strains depended on an applied dose of MOS and the strain tested, and was lower or higher in comparison to the control group fed a standard diet. Both, the in vivo and in vitro studies revealed, however, stimulating effect of MOS on adhesion of bifidobacteria to the colonic intestine, and higher amount of MOS caused stronger adhesion. The genome sequence of probiotic Lactobacillus and Bifidobacterium strains predicts the occurrence of proteins needed for the production of glycoprotein-binding fimbriae and mucus- and fibronectin-binding proteins that could be involved in the bacterial adhesion to the gastrointestinal tract (Schell et al., 2002; Pridmore et al., 2004). However, the putative fimbriae region in bifidobacteria appeared to be highly heterogenous (Maegawa et al., 2008), which 
MOS caused stronger adhesion. The genome sequence of probiotic Lactobacillus and Bifidobacterium strains predicts the occurrence of proteins needed for the production of glycoprotein-binding fimbriae and mucus- and fibronectin-binding proteins that could be involved in the bacterial adhesion to the gastrointestinal tract (Schell et al., 2002; Pridmore et al., 2004). However, the putative fimbriae region in bifidobacteria appeared to be highly heterogenous (Maegawa et al., 2008), which indicates the need for careful selection of strains for diet co-supplementation. The tested B. animalis subsp. lactis $\mathrm{BI} 30$ and $\mathrm{J} 38$ strains were isolated from fermented milk and are characterized by resistance to gastrointestinal conditions, adhesion to epithelial-like cells and high antagonistic activity against enteropathogens (Bielecka et al., 1996, 1998a,b). It creates possibilities for cosupplementation of a MOS-containing diet with these bifidobacteria; however, separate studies on successful adaptation of these bacteria to the intestinal conditions should be performed.

\section{CONCLUSIONS}

The experiment revealed that both flavomycin and mannanoligosaccharides (MOS) fed to turkeys significantly altered susceptibility of the colonic epithelium for bacterial binding, leading to the changed composition of the enteric microflora closely adjacent to the intestine. Despite of significant reduction in enterobacteria colonizing the intestine in vivo, the epithelium of flavomycin-receiving birds seems to be more susceptible to bind some $E$. coli and bifidobacteria strains, and more resistant to bind some lactobacilli. MOS seems to possess a great ability to reduce attachment of pathogenic enterobacteria, and to enhance intestinal adhesion of some beneficial bacteria, mainly bifidobacteria. Applied at higher doses, it significantly increased live body weight. The results seem to confirm positive effect of MOS and beneficial microflora in poultry.

\section{REFERENCES}

Biedrzycka E., Bielecka M., Majkowska A., Jankowski J., 2003. The effects of Bacillus cereus var. toyoi and avilamycin on the faecal microflora of turkey. J. Anim. Feed Sci. 12, 821-832

Bielecka M., Biedrzycka E., Biedrzycka El., Smieszek M., 1996. Resistance of Bifidobacterium to gastrointestinal conditions. In: G. Venema, J.H.J. Huis In’t Veld, J. Hugenholtz (Editors). Proceedings of $5^{\text {th }}$ Symposium on Lactic Acid Bacteria 'Genetics, Metabolism and Applications'. Veldhoven (The Netherlands). Kluwer Academic Press, p. J28

Bielecka M., Biedrzycka El., Biedrzycka E., Smoragiewicz W., Smieszek M., 1998b. Interaction of Bifidobacterium and Salmonella during associated growth. Int. J. Food Microbiol. 45, 151-155 
Bielecka M., Biedrzycka E., Frejnagel S., 1998a. Scanning and light microscopy to study the adhesion of the Bifidobacterium. Pol. J. Food Nutr. Sci. 7/48, 108-115

Brzóska F., Buluchevskij S., Stecka K., Śliwinski B., 2007. The effects of lactic acid bacteria and mannan oligosaccharide, with or without fumaric acid, on chicken performance, slaughter field and digestive tract microflora. J. Anim. Feed Sci. 16, 241-251

Close B., Banister K., Baumans V., Bernoth E.-M., Bromage N., Bunyan J., Erhardt W., Flecknell P., Gregory N., Hackbarth H., Morton D., Warwick C., 1997. Recommendations for euthanasia of experimental animals: Part 2. Lab. Animals 31, 1-32

Doeschate R.A.H.M., Kenyon S., 1999. Alternatives to antibiotic growth promoters: mannanoligosaccharides and organic acids. In: L.G. Cavalchini, D. Baroli (Editors). Proceedings of XIV European Symposium on the Quality of Poultry Meat. Bologna (Italy). WPSA, pp. 203-207

Elmusharaf M.A., Bautista V., Nollet L., Beynen A.C., 2006. Effect of mannanoligosaccharide preparation on Eimeria tenella infection in broiler chicken. Int. J. Poultry Sci. 5, 583-588

Heyndrickx M., Vandekerchove D., Herman L., Rollier I., Grijspeerdt K., De Zutter L., 2002. Routes for Salmonella contamination of poultry meat: epidemiological study from hatchery to slaughterhouse. Epidemiol. Infect. 129, 253-265

Hooge D.M., 2004. Meta-analysis of broiler chicken pen trials evaluating dietary mannan oligosaccharide, 1993-2003. Int. J. Poultry Sci. 3, 163-174

Iji P.A., Saki A.A., Tivey D.R., 2001. Intestinal structure of broiler chickens on diets supplemented with a mannanoligosaccharide. J. Sci. Food Agr. 81, 1186-1192

Lin W.H., Yub B., Jange H.S., Tsen H.Y., 2007. Different probiotic properties for Lactobacillus fermentum strains isolated from swine and poultry. Anaerobe 13, 107-113

Maegawa T., Nishitani Y., Osawa R., 2008. Polymorphism of gene associated with putative fimbriae of Bifidobacterium longum strains, with specific reference to their host specific colonization. Biosci. Microflora 27, 49-56

Markiewicz L.H., Biedrzycka E., Wasilewska E., Bielecka M., 2009. Differentiation of strains identified as Bifidobacterium animalis subsp. lactis. Acta Aliment. 38, 293-301

Pridmore R.D., Berger B., Desiere F., Vilanova D., Barretto C., Pittet A.C., Zwahlen M.C., Rouvet M.C., Altermann E., Barrangou R., Mollet B., Mercenier A., Klaenhammer T., Arigoni F., Schell M.A., 2004. The genome sequence of the probiotic intestinal bacterium Lactobacillus johnsonii NCC 533. Proc. Nat. Acad. Sci. USA 101, 2512-2517

Rambaud J.C., Buts J.P., Corthier G., Flourie B., 2006. Gut Microflora Digestive Physiology and Pathology. John Libbey Eurotext. Paris (France)

Schell M.A., Karmirantzou M., Snel B., Vilanova D., Berger B., Pessi G., Zwahlen M.C., Desiere F., Bork P., Delley M., Pridmore R.D., Arigoni F., 2002. The genome sequence of Bifidobacterium longum reflects its adaptation to the human gastrointestinal tract. Proc. Nat. Acad. Sci. USA 99, 14422-14427

Sims M.D., Dawson K.A., Newman K.E., Spring P., Hooge D.M., 2004. Effects of dietary mannan oligosaccharide, bacitracin methylene disalicylate, or both on the live performance and intestinal microbiology of turkeys. Poultry Sci. 83, 1148-1154

Swanson K.S., Grieshop C.M., Flickinger E.A., Bajer L.L., Healy H.P., Dawson K.A., Merchen N.R., Fahey G.C., 2002. Supplemental fructooligosaccharides and mannanoligosaccharides influence immune function, ileal and total tract nutrient digestibilities, microbial populations and concentrations of protein catabolites in the large bowel of dogs. J. Nutr. 132, 980-989

Tierney J., Gowing H., Van Sidersen D., Flynn S., Stanley L., McHallahan S., Mulchahy G., 2004. In vitro inhibition of Eimeria tenella invasion by indigenous chicken Lactobacillus species. Vet. Parasitol. 122, 171-182 
Wasilewska E., Bielecka M., Markiewicz L., 2003. Numerical analysis of biochemical and morphological features of bifidobacteria as a tool for species characteristics and identification. Pol. J. Food Nutr. Sci. 12/53, 149-156

Wasilewska E., Markiewicz L.H., Bielecka M., 2008. Bifidobacterium strains inhabiting the gastrointestinal tract of rat as potential probiotics for animals. J. Anim. Feed Sci. 17, 398-410

Yang Y., Iji P.A., Choct M., 2009. Dietary modulation of gut microflora in broiler chickens: a review of the role of six kinds of alternatives to in-feed antibiotics. World Poultry Sci. J. 65, 97-114

Yang Y., Iji P.A., Kocher A., Mikkelsen L.L., Choct M., 2007. Effects of mannanoligosaccharide on growth performance, the development of gut microflora, and gut function of broiler chickens raised on new litter. J. Appl. Poultry Res. 16, 280-288

Yang Y., Iji P.A., Kocher A., Thomson E., Mikkelsen L.L., Choct M., 2008. Effects of mannanoligosaccharide in broiler chicken diets on growth performance, energy utilisation, nutrient digestibility and intestinal microflora. Brit. Poultry Sci. 49, 186-194

Yu B., Tsen H.Y., Chiou P.W.S., 1999. Caecal culture enhances performance and prevents Salmonella infection in broilers. J. Appl. Poultry Res. 8, 195-204

Zdunczyk Z., Juskiewicz J., Jankowski J., Biedrzycka E., Koncicki A., 2005. Metabolic response of gastrointestinal tract of turkeys to diets with different levels of mannanoligosaccharide. Poultry Sci. 84, 903-909 